\title{
EVALUATION OF THE EFFECTIVENESS OF ELECTROMAGNETIC TREATMENT OF WELL WATER
}

\author{
${ }^{1}$ A.S.Berdishev, ${ }^{1}$ Z.Z.Djumaboyeva. \\ ${ }^{1}$ Tashkent institute of engineers of agriculture irrigation and machenization.
}

\begin{abstract}
The article presents the results of investigation on wastewater purification from various contaminants and bacteriological infections by the method of physical-chemical treatment. The paper substantiates the choice of effective methods of ozonation by physical fields, in particular by electromagnetic ones. The results are substantiated experimentally and make it possible to continue research in the chosen line.
\end{abstract}

\section{Introduction}

In the hot climate of Uzbekistan, providing the population with good-quality drinking water is of great social, hygienic and anti-epidemic significance. This is due to the fact that water is a way of spreading various diseases related to the group of intestinal infections (typhoid fever, paratyphoid fever, viral hepatitis and many others) [1-4]. The situation is aggravated by the fact that many water sources, including underground ones, are polluted and the quality of water in them, especially bacteriological, is deteriorating. As a result, water analysis performed by the supervisory authority from many wells and boreholes, including those located on the territory of the Tashkent region, do not meet health and hygiene standards during research conducted.

The rules specify that if the quality of water in a water source is deteriorated, it is necessary to retest according to the health and hygiene standards.

Since the level of bacterial contamination of drinking water can vary widely, different methods of disinfection are used in practice. Chlorination of water is most often used; for underground water sources are recommended ultraviolet treatment of drinking water. Recently, lowfrequency pulsed electromagnetic treatment of drinking water has been proposed as an alternative method.

Unfortunately, until very recently, the usage of this purification type in Republic of Uzbekistan was not widely spread and there was not the health and hygiene assessment of their work and efficiency. At the same time, it was simultaneously recognized that it was necessary to carry out additional health and hygiene researches in order to determine the optimal operating modes of the installation, differentiation of the bactericidal effect in relation to different microbes, identification of promising areas for the use of highly effective installations and chemicals [5-8].

\section{Main part}

Methodology of work. Laboratory studies included the determination of water oxidizability, the content of ammonia, nitrites and nitrates, the total number of microbes in $1 \mathrm{ml}$ of water and the coli-index, as well as enteropathogenic bacteria. Standard research methods were used.

In total, 3 cycles of experiment were carried out both with water from a well and with artificially polluted one. The main object of observation was well No. 2, located on the territory of the automobile plant. The water quality, according to the Health and Epidemiology Service, fluctuated significantly during 2018, in particular the coliindex deteriorated to 43 . In the nearby well No. 1 , water from which also is used, the water quality was sometimes even lower, and coli-index was up to 93 [9-12].

The process of electromagnetic treatment of water from a well was carried out with different operation modes: the irradiation frequency was $1.66 ; 6 ; 8 ; 10 ; 15$; and $20 \mathrm{~Hz}$, processing time was different in field and laboratory researches.

The research cycles were 5-7 days and were performed in December 2018 (December 1-8, December 9-16 and December 17-24).

Research results. Before electromagnetic treatment, the chemical analyses of water from the investigated wells showed that the water was practically not contaminated with organic compounds. As can be seen from Table 1, there were no nitrogen compounds in water, and the oxidizability of water was $3,1 \mathrm{mg} / \mathrm{l}(\mathrm{pH} 7.8)$.

Electromagnetic treatment of water for several seconds slightly reduced the oxidizability of water, reducing it to $1.82-2.3 \mathrm{mg} / \mathrm{l}(\mathrm{pH} 7.87-7.97)$. It was not possible to establish a link to the decrease in the oxidizability of water depending on the processing frequencies (from 1.66 to 20 $\mathrm{Hz}$ ).

As the water from the well proved to be of adequate quality, the investigated water was contaminated with organic compounds at the laboratory. As a result the content of ammonia reached $0.57 \mathrm{mg} / \mathrm{l}$, nitrites -0.012 $\mathrm{mg} / \mathrm{l}$ and nitrates $-0.5 \mathrm{mg} / \mathrm{l}$. After treatment through the electromagnetic installation with a frequency of $10 \mathrm{~Hz}$, the content of nitrogen compounds decreased by $40-60 \%$ : ammonia up to $0.17 \mathrm{mg} / \mathrm{l}$, nitrites $-0.0046 \mathrm{mg} / \mathrm{l}$ and nitrates $-0.3 \mathrm{mg} / \mathrm{l}$.

In a special series of experiments, an attempt was made to find out the effect of electromagnetic water treatment to 
the total hardness value (Table 2). Processing time during all experimental series was from 3 to 5 seconds [13-14].

Table 1. The chemical analyses of water from well No.3 after electromagnetic treatment

\begin{tabular}{|c|c|c|c|c|c|c|}
\hline No. & Frequency, $\mathrm{Hz}$ & $\begin{array}{c}\text { Ammonia, } \\
\mathrm{mg} / \mathrm{l}\end{array}$ & Nitrites, $\mathrm{mg} / \mathrm{l}$ & Nitrates, $\mathrm{mg} / \mathrm{l}$ & Oxidizability, $\mathrm{mg} / \mathrm{l}$ & $\mathrm{pH}$ \\
\hline 1 & control & 0 & 0 & 0 & 3.12 & 7.8 \\
\hline 2 & 1.66 & 0 & 0 & 0 & 2.3 & 7.94 \\
\hline 3 & 6.0 & 0 & 0 & 0 & 2.02 & 7.95 \\
\hline 4 & 8.0 & 0 & 0 & 0 & 2.02 & 7.97 \\
\hline 5 & 10.0 & 0 & 0 & 0 & 2.02 & 7.95 \\
\hline 6 & 15.0 & 0 & 0 & 0 & 1.82 & 7.87 \\
\hline 7 & 20.0 & 0 & 0 & 0 & 2.11 & 7.94 \\
\hline
\end{tabular}

Table 2. The total hardness value of water after electromagnetic treatment

\begin{tabular}{|c|c|c|}
\hline Samples No. & Frequency, Hz & Total hardness, mg-eqv./l \\
\hline \multicolumn{3}{|c|}{1 series } \\
\hline 1 & control & 20.64 \\
\hline 2 & 1.66 & 19.44 \\
\hline 3 & 5.0 & 19.92 \\
\hline 4 & 10.0 & 17.91 \\
\hline 5 & 15.0 & 19.40 \\
\hline 6 & 20.0 & 18.70 \\
\hline \multicolumn{3}{|c|}{2 series } \\
\hline 1 & control & 15 \\
\hline 2 & 10 & 14 \\
\hline 3 & 20 & 14.3 \\
\hline \multicolumn{3}{|c|}{3 series } \\
\hline 1 & control & 3 \\
\hline 2 & 10 & 2.6 \\
\hline 3 & 20 & 2.8 \\
\hline \multicolumn{3}{|c|}{4 series } \\
\hline 1 & control & 2 \\
\hline 2 & 1.66 & 1.6 \\
\hline 3 & 5 & 1.4 \\
\hline 4 & 10 & 1 \\
\hline 5 & 15 & 1.44 \\
\hline 6 & 20 & 1.3 \\
\hline
\end{tabular}


As can be seen from Table 2, at high level of total hardness, the degree of its decrease after electromagnetic treatment does not exceed.OD At low values (2.0-3.0 mgeqv./l) it increases to $20-30 \%$. However, the conclusion on the influence of electromagnetic treatment on the level of total water hardness requires deeper chemical investigations of various types of surface and ground water after different duration of its treatment [15-18]. As electromagnetic water treatment is supposed to be used as an alternative method of disinfection, the main attention was paid to hygienic and bacteriological analysis of well water. The results were compared with health and hygiene standards for drink water: the total number of microbes in $1 \mathrm{ml}$ - no more than 100, coli-index - no more than 3, no enteropathogenic bacteria [19-25].

The bacteriological analyses (first series of experiments) were conducted of well water treated directly on the territory of the automobile plant No. 3. As can be seen from Table 3, the well water turned out to be adequate quality according to the investigated indicators: total bacterial count in $1 \mathrm{ml}(\mathrm{TBC} / \mathrm{ml})-4$, coli-index -4 , enteropathogenic bacteria was not detected.

Table 3. Bacteriological analyses of water from the well No. 3 (culture date: 8 December 2018)

\begin{tabular}{|l|l|l|l|l|l|}
\hline $\begin{array}{l}\text { Sample } \\
\text { No. }\end{array}$ & Sample type & TBC/ml & $\begin{array}{l}\text { Coli- } \\
\text { index }\end{array}$ & $\begin{array}{l}\text { Enteropathogenic } \\
\text { bacteria }\end{array}$ & $\begin{array}{l}\text { wequirements of State } \\
\text { standard (GOST) for } \\
\text { "Drink water" }\end{array}$ \\
\hline 1 & Untreated water - control & 4 & 4 & Not identified & No \\
\hline 2 & Treated water $-1.66 \mathrm{~Hz}$ & 1 & 4 & Not identified & No \\
\hline 3 & Treated water $-4 \mathrm{~Hz}$ & 1 & 4 & Not identified & No \\
\hline 4 & Treated water $-6 \mathrm{~Hz}$ & 0 & 4 & Not identified & No \\
\hline 5 & Treated water $-3 \mathrm{~Hz}$ & 2 & $<3$ & Not identified & Yes \\
\hline 6 & Treated water $-10 \mathrm{~Hz}$ & 1 & $<3$ & Not identified & Yes \\
\hline 7 & Treated water $-15 \mathrm{~Hz}$ & 8 & $<3$ & Not identified & Yes \\
\hline 8 & Treated water $-20 \mathrm{~Hz}$ & 1 & $<3$ & Not identified & Yes \\
\hline
\end{tabular}

When the frequency of treatment was from 1.66 to $6 \mathrm{~Hz}$, the effect was insignificant, but at higher frequencies the coli-index in all experiments was less than 3. It meets the requirements of the drinking water standard.
Similar results were occurred in second series of experiments in December 2018 (Table 4).

Table 4. Bacteriological analyses of water from the well No. 3 (culture date: 15 December 2018)

\begin{tabular}{|l|l|l|l|l|l|}
\hline $\begin{array}{l}\text { Sample } \\
\text { No. }\end{array}$ & Sample type & TBC/ml & $\begin{array}{l}\text { Coli- } \\
\text { index }\end{array}$ & $\begin{array}{l}\text { Enteropathogenic } \\
\text { bacteria }\end{array}$ & $\begin{array}{l}\text { Compliance with the } \\
\text { requirements of State } \\
\text { standard (GOST) for } \\
\text { "Drink water" }\end{array}$ \\
\hline 1 & Untreated water - control & 5 & 4 & No & No \\
\hline 2 & Treated water $-8 \mathrm{~Hz}$ & 1 & 3 & No & Yes \\
\hline 3 & Treated water $-12 \mathrm{~Hz}$ & 4 & 3 & No & Yes \\
\hline 4 & Treated water $-20 \mathrm{~Hz}$ & 3 & 3 & No & Yes \\
\hline
\end{tabular}

Later, realizing that artificial contamination of the source water under natural conditions is impossible, two series of experiments were carried out with artificial contamination of the source water with a culture of colibacillus: in $3^{\text {rd }}$ series it was introduced at the rate of 100 cells per $1 \mathrm{ml}$ of water (extremely massive contamination), in $4^{\text {th }}$ series at the rate of 10 and 100 cells per 1 liter of water (at the level of water pollution in the wells of the automobile plant No. 3, observed by the Sanitary and Epidemiological Services during 2018) [26-28].
As can be seen from Table 5, in case of massive contamination of the initial water from the well with a culture of colibactera in the control sample, the run of electromagnetic treatment was 109 in $1 \mathrm{ml}$, and the coliindex was more than 1,100 , enteropathogenic bacteria were not detected. Electromagnetic treatment of such water at different frequencies was ineffective: TBC did not decrease below 109 in $1 \mathrm{ml}$, and the coli-index was more than 1,100 in all samples, that is, it remained at the same level. In general, such a result can be considered 
common, since it is known that, for example, ultraviolet irradiation of water is effective only when the contamination of Escherichia coli is below 1,000. It should also be noted that the time of electromagnetic treatment of water remained very short (about $3-5 \mathrm{sec}$ ).

Table 5. Results of bacteriological studies of artesian water delivered from automobile plant No. 3 with preliminary culture introduction. Sowing date 15 Dec 2018

\begin{tabular}{|c|c|c|c|c|}
\hline Sample type & $\begin{array}{l}\text { Micro- } \\
\text { organisms , / } \\
\text { ml }\end{array}$ & $\begin{array}{l}\text { Coli } \\
\text { index }\end{array}$ & $\begin{array}{l}\text { Pathogenic } \\
\text { microorganisms }\end{array}$ & $\begin{array}{l}\text { Compliance with the } \\
\text { requirements of GOST } \\
\text { 2874-82 "Drinking } \\
\text { water" }\end{array}$ \\
\hline $\begin{array}{l}\text { Artesian water with artificial } \\
\text { culture introduction at a dose of } \\
100 \text { cells / ml (control) }\end{array}$ & 109 & $\begin{array}{l}\text { More } \\
\text { than } \\
1100\end{array}$ & not found & No \\
\hline $\begin{array}{l}\text { Artesian water with artificial } \\
\text { introduction of culture at a dose of } \\
100 \text { cells / ml and sample. low- } \\
\text { frequency pulsed field of } 1.66 \mathrm{~Hz}\end{array}$ & 105 & $\begin{array}{l}\text { More } \\
\text { than } \\
1100\end{array}$ & not found & No \\
\hline $\begin{array}{l}\text { Artesian water } \\
\text { with artificial introduction of } \\
\text { culture at a dose of } 100 \text { cells / } \mathrm{ml} \\
\text { and sample. low-frequency pulsed } \\
\text { field of } 2.0 \mathrm{~Hz} \text {. }\end{array}$ & 128 & $\begin{array}{l}\text { More } \\
\text { than } \\
1100\end{array}$ & not found & No \\
\hline $\begin{array}{l}\text { Artesian water } \\
\text { with artificial introduction of } \\
\text { culture at a dose of } 100 \text { cells / } \mathrm{ml} \\
\text { and sample. low-frequency pulsed } \\
\text { field of } 4.0 \mathrm{~Hz} \text {. }\end{array}$ & 118 & $\begin{array}{l}\text { More } \\
\text { than } \\
1100\end{array}$ & not found & No \\
\hline $\begin{array}{l}\text { Artesian water } \\
\text { with artificial introduction of } \\
\text { culture at a dose of } 100 \text { cells } / \mathrm{ml} \\
\text { and sample. low-frequency pulsed } \\
\text { field } 6.0 \mathrm{~Hz}\end{array}$ & 130 & $\begin{array}{l}\text { More } \\
\text { than } \\
1100\end{array}$ & not found & No \\
\hline $\begin{array}{l}\text { Artesian water with artificial } \\
\text { introduction of culture at a dose of } \\
100 \text { cells / ml and sample. low- } \\
\text { frequency pulsed field } 8.0 \mathrm{~Hz}\end{array}$ & 106 & $\begin{array}{l}\text { More } \\
\text { than } \\
1100\end{array}$ & not found & Does not match \\
\hline $\begin{array}{l}\text { Artesian water with artificial } \\
\text { introduction of culture at a dose of } \\
100 \text { cells / ml and sample. low- } \\
\text { frequency pulsed field of } 10 \mathrm{~Hz}\end{array}$ & 155 & $\begin{array}{l}\text { More } \\
\text { than } \\
1100\end{array}$ & not found & Does not match \\
\hline $\begin{array}{l}\text { Artesian water } \\
\text { with artificial introduction of } \\
\text { culture at a dose of } 100 \text { cells / ml } \\
\text { and sample. low-frequency pulsed } \\
\text { field of } 15 \mathrm{~Hz}\end{array}$ & 118 & $\begin{array}{l}\text { More } \\
\text { than } \\
1100\end{array}$ & not found & Does not match \\
\hline $\begin{array}{l}\text { Artesian water } \\
\text { with artificial } \\
\text { introduction of culture at a dose of } \\
100 \text { cells / ml and sample. low- } \\
\text { frequency pulsed field of } 20 \mathrm{~Hz}\end{array}$ & 121 & $\begin{array}{l}\text { More } \\
\text { than } \\
1100\end{array}$ & not found & Does not match \\
\hline
\end{tabular}


Table 6. Results of bacteriological studies of artesian water delivered from automotive plant No. 3 with preliminary introduction of 8 coli cultures. (Sowing date 23 Dec 2018)

\begin{tabular}{|c|c|c|c|c|c|c|c|}
\hline \multirow{3}{*}{$\begin{array}{l}\text { No. } \\
\text { p.p. }\end{array}$} & \multirow[t]{3}{*}{ Sample type } & \multicolumn{6}{|c|}{ COLI-INDEX } \\
\hline & & \multirow[t]{2}{*}{ Control } & \multicolumn{4}{|c|}{ Low frequency pulsed field processing in $\mathrm{Hz}$} & \multirow{2}{*}{$\begin{array}{l}\text { Water } \\
\text { filtered } \\
\text { with } \\
\text { sorbent }\end{array}$} \\
\hline & & & $10 \mathrm{hz}$ & $20 \mathrm{hz}$ & $\begin{array}{l}10 \mathrm{~Hz} \text { and } \\
\text { filtered with } \\
\text { sorbent }\end{array}$ & $\begin{array}{l}20 \mathrm{~Hz} \text { and } \\
\text { filtered } \\
\text { with } \\
\text { sorbent }\end{array}$ & \\
\hline 1 & $\begin{array}{l}\text { Water } \\
\text { with artificial introduction } \\
\text { of } 8 \text { coli culture at a dose } \\
\text { of } 10 \mathrm{kl} / 1\end{array}$ & 23 & 7 & 3 & 11 & 3 & 11 \\
\hline 2 & $\begin{array}{l}\text { Water } \\
\text { with artificial introduction } \\
\text { of } 8 \text { coli culture at a dose } \\
\text { of } 100 \mathrm{kl} / 1\end{array}$ & 120 & 7 & 3 & 23 & 4 & 43 \\
\hline
\end{tabular}

Table 4.

\begin{tabular}{|c|c|c|c|}
\hline Years & $\begin{array}{c}\text { Calculated energy } \\
\text { consumption } \mathrm{kW} / \mathrm{h}\end{array}$ & $\begin{array}{c}\text { Actual energy consumption } \\
\mathrm{kW} \text { *h }\end{array}$ & $\begin{array}{c}\text { Difference }(+) \text { cost } \\
\text { overruns }(-) \text { economics }\end{array}$ \\
\hline 2018 & 22789140,85 & 15962583 & $-6826557,85$ \\
\hline 2019 & 16462628,7 & 16242862 & $-219766,7$ \\
\hline $\begin{array}{c}2020 \\
(9 \text { month) }\end{array}$ & 18710403,96 & 15576015 & $-3134388,96$ \\
\hline
\end{tabular}

In $4^{\text {th }}$ series of experiments, when the water was contaminated with smaller doses of Escherichia coli cultures, the electromagnetic treatment of water turned out to be more effective, especially since the processing time was increased to 3 minutes (Table 6). As can be seen from this table, the most effective treatment turned out to be with a frequency of 20 hertz; in this case, the coli-index of water decreased from 23 to 3 and from 120 to 3-4. Additional filtration through the sorbent proved to be ineffective. One filtration through a sorbent reduced the coli index from 23 to 11, from 120 to 43. Note: water treatment by low-frequency pulsed field produced within 3 min [29-31].

\section{Conclusions}

1. Since the source water did not contain nitrogen compounds, and the oxidizability values were insignificant, it was not possible to check the effectiveness of electromagnetic treatment of water in relation to these indicators in natural conditions. reducing the content of nitrogen compounds by $40-50 \%$.
2. At high values of the total hardness of the initial water (15-20 mg-eq / 1), electromagnetic treatment reduced it by $10 \%$, at low values $(2-3 \mathrm{mg}$-eq / 1$)$, the reduction effect increased to $20-30 \%$. These data require additional confirmation.

3. Against the background of the level of sanitary bacteriological pollution of water from the well observed in December, its treatment with a frequency of 1.66-6 Hertz turned out to be ineffective, with a frequency of 620 Hertz the coli-index values corresponded to those of GOST "Drinking water" (less than 3) 5. If massive contamination of the initial water by the culture of Escherichia coli cultures (100 cells per $1 \mathrm{ml}$ of water), its electromagnetic treatment for 3-5 seconds turned out to be ineffective in the control, and in all experimental samples the coli index was more than 1,100 .

4. The conducted studies allow us to consider the use of electromagnetic treatment as a rather promising method for disinfecting slightly contaminated groundwater. However, since the use of this method can be limited in conditions of significant fluctuations in sanitary and bacteriological indicators of the quality of the treated source water (including seasonal in nature), we consider it necessary:

implementation of constant laboratory control over the quality of the source water from the wells of the automobile plant No. 3 throughout the year by the 
territorial bodies of the Sanitary and Epidemiological Service; and

carrying out in-depth studies on these wells similar to those described in this report, in the most unfavorable season of the year in terms of groundwater pollution.

5. In case of using this method on a wider scale, we consider it necessary to conduct special studies, according to the hygienic assessment, of the proposed method of electromagnetic treatment of water in different operating modes of the installation (in terms of time, frequency used, etc.)

Such works, in case of their positive result, can serve as a basis for obtaining permission from the Ministry of Health of the Republic of Uzbekistan to introduce this method and relevant facilities in the sectors of the economy.

\section{References}

1. Dmitriyeva V.I., Nikitin V.A., Polenina V.A. Ispol'zovaniye stokov zhivotnovodcheskikh kompleksov. -M.: Agropromizdat, 2007. -64 s.

2. Batsanov I.I., Luk'yanenkov I.I. Uborka i utilizatsiya navoza na svinovodcheskikh komplektsakh . -M.: Agropromizdat, 2010. -160 s

3. Polyakov A.A. Veterinarnaya sanitariya. -M.: Agropromizdat, 2008.-232 s.

4. Krupnyye zhivotnovodcheskiye kompleksy i okruzhayushchaya sreda. Pod red. Nikitina D.P. - M.: Meditsina, 2000. - $256 \mathrm{~s}$

5. Kokurin V.A. Issledovaniye usloviy obezzarazhivaniya stochnykh vod mikrobiologicheskogo ob"yeta: Avtoref. Diss. ... kand. Biol. Nauk. -M., 2005. -16 s.

6. Voznaya N.F. Khimiya vody i mikrobiologiya. - M.: Vysshaya shkola, 2009. -342 s

7. Votootvedeniye stochnykh vod Yakovlev S.V., Karemin YA.A., Laskov YU.M. -M.: Stroyizdat, 2006, 586 s.

8. Mnukhin A.G. Bryukhanov A.M. Obezzorazhivaniye poverkhnostnykh i stochnykh vod s pomoshch'yu elektrogidravlicheskogo vozdeystviya. Vodosnabzheniye i sanitarnaya tekhnika - 2002 -№11s. $18-19$

9.Taslimov, A.D., Rakhmonov, I.U. (2019) Optimization of complex parameters of urban distribution electric networks Journal of Physics: Conference Series 1399 doi:10.1088/1742-6596/1399/5/055046

10.Rakhmonov, I.U., Niyozov, N.N. (2019) Optimization setting of steel-smelting industry in the issue of alloy steels E3S Web Conf 139 doi:10.1051/e3sconf/201913901077

11.Rakhmonov, I.U., Reymov, K. M., Shayumova, Z.M. (2019) The role information in power management tasks. E3S Web Conf 139 doi:10.1051/e3sconf/201913901080 12.Rakhmonov, I.U., Reymov, K.M. (2019) Mathematical Models and Algorithms of Optimal Load Management of Electricity Consumers J ENERGETIKA.
Proceedings of CIS higher education institutions and power engineering association 62(6) pp 528-535 doi:10.21122/1029-7448-2019-62-6-528-535

13.Rakhmonov, I. U., Tovbaev, A.N., Nematov, L.A., Alibekova,T.Sh. (2020) Development of forecasted values of specific norms for the issues of produced products in industrial enterprises Journal of Physics: Conference Series $\mathbf{1 5 1 5}$ doi:10.1088/17426596/1515/2/022050

14.Rakhmonov, I.U., Nematov, L.A., Niyozov, N.N, Reymov, K.M., Yuldoshev, T.M. (2020) Power consumption management from the positions of the general system theory Journal of Physics: Conference Series 1515 doi:10.1088/1742-6596/1515/2/022054

15.Rakhmonov, I.U., Reymov, K.M., Najimova, A.M., Uzakov, B.T., Seytmuratov, B.T. (2019) Analysis and calculation of optimum parameters of electric arc furnace Journal of Physics: Conference Series 1399 doi:10.1088/1742-6596/1399/5/055048

16.Rakhmonov, I.U., Reymov, K.M. (2019) Regularities of change of energy indicators of the basic technological equipment of the cotton-cleaning industry Journal of Physics: Conference Series 1399 doi:10.1088/17426596/1399/5/055038

17.Rakhmonov, I. U., Reymov, K.M., Dustova, S.H. (2020) Improvements in industrial energy rationing methods Journal of IOP: Conference Series. MIP: Engineering-2020. 862 (2020) 062070 doi:10.1088/1757899X/862/2/062070

18.Rakhmonov, I.U., Berdishev, A.A., Niyozov, N.N., Muratov, A., Khaliknazarov U. (2020) Development of a scheme for generating the predicted value of specific electricity consumption Journal of IOP: Conference Series. MIP: Engineering-2020. 883 (2020) 012103 doi:10.1088/1757-899X/883/1/012103

19.Rakhmonov, I.U., Berdishev, A.A., Khusanov, B.M., Khaliknazarov, U., Utegenov, U. (2020) General characteristics of networks and features of electricity consumers in rural areas Journal of IOP: Conference Series. MIP: Engineering-2020. 883 (2020) 012104 doi:10.1088/1757-899X/883/1/012104

20.Hoshimov, F.A., Bakhadirov, I.I., Erejepov, M., Djumamuratov, B. (2019) Development of method for normalizing electricity consumption E3S Web Conf 139 doi:10.1051/e3sconf/201913901074

21.Karimov R.Ch., Bobojanov M.K., Rasulov A.N., Usmanov E.G. E3S Web of Conferences, 139, 01039, (2019), doi.org/10.1051/e3sconf/201913901039;

22.Karimov R.Ch., Shamsiyev K., and others. IOP Conf. Series: Materials Science and Engineering, 883(1), 012142, (2020). doi:10.1088/1757-899X/883/1/012142;

23.E.G.Usmanov, A.N.Rasulov, M.K.Bobojanov, R.Ch.Karimov. E3S Web of Conferences 139, 01079 (2019), doi.org/10.1051/e3sconf/201913901079;

24.Karimov R.Ch., Shamsiyeva N. and others. IOP Conf. Series: Materials Science and Engineering, 883(1), 012120, (2020). doi:10.1088/1757-899X/883/1/012120 25.G.R.Rafikova, M.R.Ruzinazarov, S.K.Makhmutkhonov. E3S Web of Conferences, 139, 01075,

https://doi.org/10.1051/e3sconf/201913901075
(2019), 
26.Khakimov,H.T., Shayumova,Z.M., Kurbanbaeva,Z.K. , Khusanov,B.M. Development of optimal modes and mathematical models of energy performance of electric steelmaking production//E3S Web of Conferences, 2019, 139, 01076

27.Khushnud Sapaev and Shukhrat Umarov. Two approaches for automating analysis of electromagnetic processes in non-linear circuits with valves. Web of Conferences https://doi.org/10.1051/e3sconf/20191390 E 3S 139 (2019) 101085 RSES 20198

28.Allayev, K.R., Fedorenko, G.M.,Postnikov, V.I.,Ostapchuk, L.B. Asynchronous generators as power system's natural dampers. 43rd International Conference on Large High Voltage Electric Systems 2010, CIGRE 20102010, 9p43rd International Conference on Large High Voltage Electric Systems 2010, CIGRE 2010; Paris; France; 22 August 2010.

29.Fazylov, Kh.F.,Allaev, K.R. Analysis of the operation of an electrical system during simultaneous operation of synchronous and asynchronous generators. Power engineering New York Volume 18, Issue 3, 1980, Pages 81-88.

30.Fazylov, Kh.F.,Allaev, K.R. Asynchronous turbogenerators with stator excitation and the prospects for their utilization. Power engineering New York Volume 23, Issue 2, 1985, Pages 7-13.

31.Fazylov, Kh.F.,Allaev, K.R. Calculation and experimental analysis of conditions of electrical power systems containing induction generators Power Engineering New York Volume 27, Issue 6, 1989, Pages 27-34. 